\title{
Bachelor of Theology
}

National Cancer Institute

\section{Source}

National Cancer Institute. Bachelor of Theology. NCI Thesaurus. Code C71354.

A bachelor's degree in theological disciplines. Candidates for this degree typically must complete course work in Greek or Hebrew, as well as systematic theology, biblical theology, ethics, homiletics and Christian ministry. 